\title{
Pengaruh Perbedaan Dosis Ekstrak Biji Jarak Pagar (Jatropha curcas) terhadap Jumlah Spermatozoa, Spermatozoa Motil, Berat Testis, dan Diameter Testis pada Mencit Jantan (Mus Musculus)
}

Haifa Wahyu', Rahmatina B. Herman ${ }^{2}$, Arni Amir $^{3}$

\begin{abstract}
Abstrak
Indonesia menghadapi persoalan kependudukan dan keluarga berencana yang cukup berat, salah satu penyebabnya dikarenakan rendahnya partisipasi pria dalam penggunaan kontrasepsi. Salah satu tanaman yang bersifat antifertilitas adalah jarak pagar (Jatropha curcas). Penelitian ini bertujuan mengetahui pengaruh perbedaan dosis ekstrak biji jarak pagar terhadap jumlah spermatozoa, spermatozoa motil, berat testis dan diameter testis pada mencit jantan (Mus musculus). Penelitian ini menggunakan metode post test only control group design terhadap mencit jantan dengan berat 20-30 gram. Sampel terdiri dari 24 ekor mencit dibagi dalam 3 kelompok P1, P2, dan P3 dengan memberikan ekstrak biji jarak pagar dengan 3 tingkatan dosis selama 36 hari. Hasil penelitian semakin tinggi dosis yang diberikan semakin rendah jumlah spermatozoa, spermatozoa motil, berat testis dan diameter testis namun secara statistik tidak terdapat pengaruh yang bermakna pada jumlah spermatozoa $p=0,06$ dan spermatozoa motil $p=0,15(p>0,05)$ dan terdapat pengaruh bermakna pada berat testis $p=0,00$ dan diameter testis $p=0,00(p<$ 0,05).Kesimpulannya pemberian ekstrak biji jarak pagar menurunkan jumlah spermatozoa, spermatozoa motil, berat testis dan diameter testis namun secara statistik ekstrak biji jarak pagar tidak terdapat pengaruh yang bermakna terhadap jumlah spermatozoa dan spermatozoa motil dan terdapat pengaruh bermakna terhadap berat testis dan diameter testis.
\end{abstract}

Kata kunci: ekstrak biji jarak pagar, jumlah spermatozoa, spermatozoa motil, berat testis, diameter testis.

\begin{abstract}
Indonesia faces the quite severe problem of population and family planning, one reason is because the low participation of men in the use of contraception. One antifertility plants and are found in Indonesia is jatropha (Jatropha curcas). This study aims to determine the effect of different doses of extract of Jatropha seeds on sperm count, motile of sperm, testis weight and diameter of the testis in male mice (Mus musculus). This study uses the approach post test only control group design to male mice weighing 20-30 grams. The sample consisted of 24 mice were divided into 3 groups of $P 1, P 2$, and $P 3$ to provide jatropha seed extract with 3 levels of doses for 36 days. The results showed the effect of Jatropha curcas seed extracts against sperm count, motile of sperm, testicular weight and testicular diameter between groups P1, P2 and P3. The higher the dose given, the lower the sperm count, motile of sperm, testis weight and diameter of the testis, but no statistically significant effect on the number of spermatozoa $p=0.06$ and $p=0.15$ motile of sperm ( $p>0.05$ ), and there is a significant effect on testis weight $p=0.00$ and $p=0.00$ testis diameter ( $p$ $<0.05)$. From the results of this study concluded that administration of Jatropha seed extract can reduce sperm count, motile of sperm, testis weight and diameter of the testis but statistically jatropha seed extract contained no significant effect on sperm count and motile of sperm and significant effect on testis weight and the diameter of the testes.
\end{abstract}

Keywords: Jatropha seed extract, sperm numbers, motile of sperm, testis weight, testis diameter. 
Affiliasi penulis : 1. Program Studi Magister Biomedik FK UNAND (Fakultas Kedokteran Universitas Andalas, Padang), 2. Bagian Fisiologi FK UNAND, 3. Bagian Biologi FK UNAND

Korespondensi : Haifa Wahyu, email: haifa_wahyu@yahoo.co.id Telp: 085263304760

\section{PENDAHULUAN}

Indonesia menghadapi persoalan Kependudukan dan Keluarga Berencana (KB) yang cukup berat. Berdasarkan SDKI 2012, angka kelahiran total/ Total Fertility Rate (TFR) di Indonesia masih tinggi yaitu 2,6 anak per wanita. Ini artinya tidak ada penurunan TFR dalam kurun waktu 10 tahun terakhir. ${ }^{1}$ Untuk mencegah terjadinya lonjakan jumlah penduduk di Indonesia diperlukan suatu upaya pengaturan kependudukan dan keluarga berencana yang efektif dan efisien. Salah satu caranya yaitu dengan memaksimalkan program KB.

Program KB di Indonesia saat ini masih belum menunjukkan hasil yang baik. Hal ini dapat dilihat dari Laju Pertambahan Penduduk (LPP) yang mencapai angka 1,49 persen. Angka tersebut cenderung meningkat dari sebelumnya yang berada pada angka 1,45 persen. ${ }^{1}$ Salah satu masalah yang menonjol pada pendekatan pengendalian populasi dan penurunan fertilitas di Indonesia adalah rendahnya partisipasi pria dalam pelaksanaan program $\mathrm{KB}$, baik dalam praktik $\mathrm{KB}$, mendukung istri dalam penggunaan kontrasepsi, maupun sebagai motivator atau promotor dalam merencanakan jumlah anak. ${ }^{2}$ Menurut data Badan Kependudukan dan Keluarga Berencana (BKKBN) tahun 2013, Jumlah partisipasi baru KB secara nasional sampai dengan bulan Oktober 2013 sebanyak 7.059.953 peserta, dimana peserta KB pria berjumlah $6,79 \%$, diantaranya penggunaan kondom sebanyak 6,48\% dan MOP (Metode Operasi Pria) sebanyak $0,30 \%$ dari jumlah tersebut. Rendahnya partisipasi pria dalam Keluarga Berencana (KB) dikarenakan terbatasnya pilihan kontrasepsi pria yang dapat digunakan. Beberapa tahun belakangan metode kontrasepsi pria hanya kondom, vasektomi, dan penyuntikan hormon. Hasilnya belum sepenuhnya diterima masyarakat karena memberikan efek samping yang tidak dapat diabaikan, dan belum $100 \%$ mencegah kehamilan. ${ }^{3}$

Berbagai upaya penelitian telah dilakukan para peneliti untuk mendapatkan pilihan kontrasepsi pria yang memenuhi persyaratan. Penelitian kontrasepsi pria yang telah dilakukan pada hewan coba dan manusia antara lain kontrasepsi hormonal dan non hormonal. Salah satu jenis kontrasepsi pria non hormonal yang ideal adalah penggunaan bahan alam dari tanaman. ${ }^{4}$

Penelitian penggunaan bahan alam sebagai bahan pengobatan telah banyak dilakukan. Salah satu tanaman yang bersifat antifertilitas yaitu biji tanaman jarak pagar. Beberapa negara seperti, Kamboja, Vietnam dan India telah menggunakan biji jarak sebagai agensia aborsi, sedangkan masyarakat di Sudan telah menggunakan biji jarak sebagai agensia kontrasepsi. ${ }^{5}$

Biji jarak pagar juga digunakan untuk obat tradisional di Indonesia baik daunnya maupun buahnya. Menurut penelitian Ekwere $d k k$ pada tahun 2011, Biji jarak kepyar (Ricinnus communis) merupakan kontrasepsi yang sering digunakan para wanita di Rukuba, Nigeria Tengah. ${ }^{6}$

Beberapa bagian tanaman jarak pagar mempunyai banyak manfaat. Bijinya sebagai bahan pembuat biodiesel, sabun dan pestisida. Bagian daun dapat digunakan sebagai makanan ulat sutra, atau insektisida. Ekstrak daun juga mengandung antiseptik. Getahnya mengandung alkaloid jatrophine yang berkhasiat anti kanker. ${ }^{7}$ Selain itu, jarak pagar mengandung saponin, flavonoid, dan polifenol. ${ }^{8}$ Menurut penelitian Nurmilah tahun 2009, kandungan kimia dari tumbuhan jarak pagar yaitu pada daun mengandung saponin, flavonoida, tannin dan senyawa polifenol. Batang mengandung saponin, flavonoid, tannin dan senyawa-senyawa polifenol. Getahnya mengandung tannin, flavonoid dan saponin. Bijinya mengandung berbagai senyawa alkaloida, saponin, dan sejenis protein beracun yang disebut curcin. Biji mengandung 35-45\% minyak lemak, yang terdiri dari berbagai trigliserida asam palmitat, stearat, dan kurkanolat. ${ }^{9}$

Pada penelitian Nath $d k k$ pada tahun 2013 yang dilakukan secara in vitro pada spermatozoa manusia dilaporkan bahwa ekstrak kulit batang jarak kepyar dapat menurunkan motilitas dan mempengaruhi morfologi spermatozoa. Penggunaan $100 \mathrm{mg} / \mathrm{ml}$ ekstrak jarak dapat mengakibatkan 100\% spermatozoa kehilangan motilitas secara progresif. 
Penggunaan 300 mg/ml ekstrak jarak mengakibatkan spermatozoa menjadi immotile. ${ }^{10}$

\section{METODE}

Jenis penelitian ini adalah eksperimen dengan desain peneltian post test only control group design. Populasi penelitian adalah mencit jantan yang berumur 2-3 bulan, dengan berat badan kira-kira 20 30 gr. Besar sampel dalam penelitian sebanyak 24 ekor. Pembuatan ekstrak dilakukan di Laboratorium Farmakologi Fakultas Farmasi Universitas Andalas. Prosedur Kerja : Pemberian ekstrak biji jarak secara oral pada mencit dilakukan dengan spuit yang dilengkapi jarum berujung tumpul, yang telah diisi cairan ekstrak 0,25 ml. Pemberian ekstrak dilakukan setiap hari pukul 11.00 WIB selama 36 hari. Pada hari ke 37 dilakukan terminasi terhadap mencit.

Analisis Data : Data hasil penelitian diolah secara statistik, setelah dilakukan uji normalitas, ternyata data jumlah spermatozoa dan spermatozoa motil tidak terdistribusi normal maka dilanjutkan dengan uji Kruskal Wallis, sedangkan data berat testis dan diameter testis terdistribusi normal maka dilanjutkan dengan uji ANOVA dan didapatkan hasil yang bermakna, maka uji statistik kemudian dilanjutkan dengan uji Post Hoc Multiple Comparisons tipe Bonferroni untuk melihat signifikasi antar kelompok.

\section{HASIL}

Jumlah spermatozoa mencit jantan setelah pemberian ekstrak biji jarak pagar dan pengaruhnya terlihat pada tabel 1 berikut ini:

Tabel 1. Rerata Jumlah Spermatozoa Mencit Jantan setelah Pemberian Ekstrak Biji Jarak Pagar

\begin{tabular}{ccc}
\hline Kelompok & $\begin{array}{c}\text { Mean } \pm \text { SD } \\
\text { (Juta/ml) }\end{array}$ & $p$ value \\
\hline P1 & $2,09 \pm 3,30$ & \\
P2 & $1,61 \pm 2,69$ & 0,06 \\
P3 & $0,00 \pm 0,00$ & \\
\hline
\end{tabular}

Dari tabel 1 didapatkan rerata jumlah spermatozoa mencit jantan pada kelompok perlakuan menunjukkan adanya penurunan sesuai dengan semakin tinggi dosis ekstrak biji jarak yang diberikan, dimana rerata pada kelompok $\mathrm{P} 1$ yaitu $2,09 \pm 3,30$ juta/ml, pada kelompok P2 terjadi penurunan yaitu
1,61 $\pm 2,69$ juta/ml, dan pada kelompok P3 terjadi penurunan yaitu $0,00 \pm 0,00$. Didapatkan $p$ value 0,06 $(p>0,05)$, yang berarti secara statistik, tidak terdapat perbedaan yang bermakna pada pemberian ekstrak biji jarak pagar antara kelompok P1, P2 dan P3.

Spermatozoa motil mencit jantan setelah pemberian ekstrak biji jarak pagar dan pengaruhnya terlihat pada tabel 2

Tabel 2. Rerata Spermatozoa Motil Mencit Jantan setelah Pemberian Ekstrak Biji Jarak Pagar

\begin{tabular}{ccc}
\hline Kelompok & $\begin{array}{c}\text { Mean } \pm \text { SD } \\
(\mathrm{Juta} / \mathrm{ml})\end{array}$ & $p$ value \\
\hline P1 & $0,78 \pm 1,62$ & \\
P2 & $0,70 \pm 1,35$ & 0,15 \\
P3 & $0,00 \pm 0,00$ & \\
\hline
\end{tabular}

Dari tabel 2 didapatkan rerata spermatozoa motil mencit jantan pada kelompok perlakuan menunjukkan adanya penurunan spermatozoa motil, dimana rerata pada kelompok $\mathrm{P} 1$ yaitu $0,78 \pm 1,62$ juta/ml, pada kelompok P2 terjadi penurunan yaitu 0,70 \pm 1,35 juta/ml, dan pada kelompok P3 terjadi penurunan yaitu $0,00 \pm 0,00$. Pada uji statistik didapatkan $p$ value $0,15(p>0,05)$, yang berarti tidak terdapat perbedaan yang bermakna pada pemberian ekstrak biji jarak pagar terhadap rata-rata spermatozoa motil mencit jantan $(p>0,05)$ antara kelompok P1, P2 dan P3.

Berat testis mencit jantan setelah pemberian ekstrak biji jarak pagar dan pengaruhnya terlihat pada tabel 3

Tabel 3. Rerata Berat Testis Mencit Jantan setelah Pemberian Ekstrak Biji Jarak Pagar

\begin{tabular}{ccc}
\hline Kelompok & Mean \pm SD (gram) & $p$ value \\
\hline P1 & $0,08 \pm 0,02$ & \\
P2 & $0,06 \pm 0,01$ & 0,00 \\
P3 & $0,04 \pm 0,01$ & \\
\hline
\end{tabular}

Dari Tabel 3 didapatkan rerata berat testis mencit jantan menunjukkan adanya penurunan, dimana rerata pada kelompok $\mathrm{P} 1$ yaitu $0,08 \pm 0,02$ gram, pada kelompok $\mathrm{P} 2$ terjadi penurunan yaitu 0,06 $\pm 0,01$ gram, dan pada kelompok P3 terjadi penurunan yaitu $0,04 \pm 0,01$. Pada uji statistik didapatkan $p$ value $0,00(p<0,05)$, yang berarti terdapat perbedaan yang signifikan pada pemberian ekstrak biji jarak pagar 
terhadap rata-rata berat testis mencit jantan antara kelompok P1, P2 dan P3. Untuk melihat signifikasi antar kelompok perlakuan dilanjutkan dengan uji Post Hoc Test Multiple Comparisons jenis Bonferroni.

Tabel 4. Hasil Uji Post Hoc Test Multiple Comparisons Bonferroni terhadap Berat Testis Mencit Jantan

\begin{tabular}{ccc}
\hline Kelompok & P2 & P3 \\
\hline P1 & $0,02^{*}$ & $0,00^{*}$ \\
P2 & - & 0,43 \\
P3 & 0,43 & -
\end{tabular}

Ket: * terdapat perbedaan bermakna

Berdasarkan hasil uji Post Hoc Test Multiple Comparisons Bonferroni pada tabel 4 tersebut dapat diketahui bahwa terdapat perbedaan yang bermakna $(p<0,05)$ antara kelompok P1 dengan kelompok P2 yaitu 0,02 dan antara kelompok $\mathrm{P} 1$ dengan kelompok P3 yaitu 0,00, sedangkan kelompok P2 dengan kelompok P3 tidak terdapat perbedaan yang bermakna $(p>0,05)$ yaitu 0,43 .

Diameter testis mencit jantan setelah pemberian ekstrak biji jarak pagar dan pengaruhnya terlihat pada tabel 6 .

Tabel 5. Rerata Diameter Testis Mencit Jantan setelah Pemberian Ekstrak Biji Jarak Pagar

\begin{tabular}{ccc}
\hline Kelompok & Mean \pm SD $(\mathrm{cm})$ & $p$ value \\
\hline P1 & $0,59 \pm 0,04$ & \\
P2 & $0,54 \pm 0,02$ & 0,00 \\
P3 & $0,46 \pm 0,06$ & \\
\hline
\end{tabular}

Dari Tabel 5 didapatkan rerata diameter testis mencit jantan (Mus musculus) menunjukkan adanya penurunan, dimana rerata pada kelompok $\mathrm{P} 1$ yaitu $0,59 \pm 0,04 \mathrm{~cm}$, pada kelompok P2 terjadi penurunan yaitu $0,54 \pm 0,02 \mathrm{~cm}$, dan pada kelompok P3 terjadi penurunan yaitu $0,46 \pm 0,06 \mathrm{~cm}$. Pada uji statistik didapatkan $p$ value $0,00(p<0,05)$, yang berarti terdapat perbedaan yang signifikan pada pemberian ekstrak biji jarak pagar (Jatropha curcas) terhadap rata-rata diameter testis mencit jantan $(p<0,05)$ antara kelompok P1, P2 dan P3. Untuk melihat signifikasi antar kelompok dilanjutkan dengan uji Post Hoc Test Multiple Comparisons jenis Bonferroni.

Tabel 6 Hasil Uji Post Hoc Test Multiple Comparisons Bonferroni terhadap Diameter Testis Mencit Jantan

\begin{tabular}{ccc}
\hline Kelompok & P2 & P3 \\
\hline P1 & $0,03^{*}$ & $0,00^{*}$ \\
P2 & - & 0,00 \\
P3 & 0,00 & - \\
\hline
\end{tabular}

Ket: * terdapat perbedaan bermakna

Berdasarkan hasil uji Post Hoc Test Multiple Comparisons Bonferroni pada tabel 6 tersebut dapat diketahui bahwa terdapat perbedaan yang bermakna $(p<0,05)$ antara kelompok P1 dengan kelompok P2 yaitu 0,03 , kelompok P1 dengan kelompok P3 yaitu 0,00 dan kelompok P2 dengan kelompok P3 yaitu 0,00 .

\section{PEMBAHASAN}

Berdasarkan hasil penelitian didapatkan jumlah spermatozoa mencit jantan mengalami penurunan sesuai dengan semakin tinggi dosis ekstrak biji jarak pagar yang diberikan. Pada Tabel 1 terlihat bahwa terdapat penurunan rata-rata jumlah spermatozoa antara kelompok perlakuan (P1, P2 dan P3) yang diberikan ekstrak biji jarak pagar dengan dosis yang berbeda-beda selama 36 hari.

Hasil Uji statistik pada tabel 1 menunjukkan belum terdapat perbedaan yang signifikan jumlah spermatozoa pada kelompok perlakuan yang diberikan ekstrak biji jarak pagar dengan dosis yang berbedabeda (P1, P2 dan P3), dimana $p$ value adalah 0,06 ( $p$ $>0,05)$. Hal ini diduga karena dosis ekstrak biji jarak pagar yang diberikan pada masing-masing kelompok perlakuan tersebut belum tepat, sehingga jumlah spermatozoa antar kelompok tersebut tidak begitu jauh perbedaannya.

Terjadinya penurunan jumlah spermatozoa disebabkan oleh adanya kandungan Jatrophone, flavonoid, dan alkaloid pada biji jarak pagar (Jatropha curcas). Jatrophone dikenal sebagai agensia antifertilitas pada tanaman jarak pagar. ${ }^{5}$ Flavonoid termasuk ke dalam golongan fitoestrogen, yaitu sumber estrogen yang berasal dari tumbuhan yang merupakan senyawa non steroidal dan memiliki aktivitas estrogenik. ${ }^{11}$ Senyawa alkaloid umumnya 
mencakup senyawa bersifat basa yang mengandung satu atau lebih atom nitrogen sebagai bagian dari sistem siklik. ${ }^{9}$

Hasil tersebut sejalan dengan penelitian yang dilakukan oleh Nithya dkk pada tahun 2011 yang menunjukkan terdapat penurunan jumlah spermatozoa pada kelompok perlakuan dibandingkan kelompok kontrol pada pemberian $25 \mathrm{mg} / \mathrm{kgBB} /$ hari ekstrak dari akar jarak kepyar (Ricinus communis). ${ }^{12}$

Penelitian ini juga sejalan dengan penelitian yang dilakukan oleh Sudarmaji dkk pada tahun 2009 yang menunjukkan bahwa ekstrak biji jarak kepyar dengan dosis $2 \mathrm{ml} / 100$ gramBB/hari selama 5 hari berturut-turut menurunkan 64,2\% - 90,7\% jumlah sperma aktif tikus jantan. ${ }^{13}$ Penelitian Sandhyakumari dkk pada tahun 2003 melaporkan bahwa Jarak kepyar menyebabkan penurunan jumlah sperma tikus, kelainan pergerakan dan morfologi sperma, serta terjadinya reduksi testosteron. ${ }^{14}$

Berdasarkan hasil penelitian didapatkan spermatozoa motil mencit mengalami penurunan sesuai dengan semakin tingginya dosis ekstrak biji jarak pagar yang diberikan. Pada Tabel 2 terlihat bahwa terdapat penurunan spermatozoa motil antara kelompok kelopok perlakuan P1, P2, dan P3 setelah diberikan ekstrak biji jarak pagar.

Hasil Uji statistik pada tabel 2 menunjukkan bahwa tidak terdapat perbedaan yang signifikan pada spermatozoa motil antara kelompok perlakuan (P1, P2 dan P3) yang diberikan ekstrak biji jarak pagar dengan dosis yang berbeda-beda selama 36 hari. dimana $p$ value adalah $0,15(p>0,05)$. Hal ini diduga karena dosis ekstrak biji jarak pagar yang diberikan antar kelompok perlakuan tersebut belum tepat, sehingga spermatozoa motil antar kelompok tersebut tidak begitu jauh perbedaannya.

Terjadinya penurunan spermatozoa motil disebabkan oleh adanya kandungan Jatrophone, flavonoid dan alkaloid pada biji jarak pagar. Jatrophone diketahui memiliki efek estrogenik yang dapat memberikan umpan balik negatif ke hipofisis anterior sehingga sekresi Follicle Stimulating Hormone (FSH) dan Luteinezing Hormone (LH) dihambat. Menurut Asfahani $d k k$ pada tahun 2010, Flavonoid mampu merangsang pembentukan estrogen dalam tubuh yang akan meningkatkan kadar estrogen. Kadar estrogen akan memberikan umpan balik negatif ke hipofisis anterior, yaitu tidak melepaskan FSH dan LH. Penurunan kadar LH menyebabkan gangguan terhadap sekresi testosteron oleh sel leydig. Dengan adanya gangguan terhadap sekresi testosteron maka motilitas spermatozoa menjadi terganggu. ${ }^{15}$

Penurunan spermatozoa motil juga dapat disebabkan oleh senyawa alkaloid. Alkaloid didefinisikan sebagai senyawa yang bersifat basa, mengandung atom nitrogen berasal dari tumbuhan dan hewan. Alkaloid merupakan golongan fitoestrogen. Alkaloid memiliki efek hormonal khususnya efek estrogenik. Alkaloid juga diduga dapat mengganggu aktivitas enzim Adenosine Triphosphatase (ATP-ase) pada membran sel spermatozoa di bagian tengah ekor. Enzim ATP-ase tersebut berfungsi mempertahankan homeostasis internal untuk ion natrium dan kalium. Jika aktivitas enzim ATP-ase terganggu, maka homeostasis ion natrium dan kalium terganggu sehingga konsentrasi natrium intrasel meningkat, gradien natrium melintasi membran sel akan menurun, sehingga pengeluaran kalsium juga akan mengalami penurunan. ${ }^{16}$ Apabila ion kalsium berkurang maka membran akan kehilangan kemampuannya untuk mengangkut bahanbahan terlarut ke dalam sitoplasma. ${ }^{17}$ Dengan terganggunya permeabilitas membran sperma akan menyebabkan terganggunya transpor nutrien yang diperlukan oleh spermatozoa untuk pergerakannya.

Berdasarkan hasil penelitian terlihat bahwa terjadi penurunan berat testis mencit jantan setelah dilakukan pemberian ekstrak biji jarak pagar dengan beberapa tingkat dosis. Hasil penelitian pada tabel 3 menunjukkan bahwa terdapat penurunan berat testis pada kelompok yang diberi ekstrak biji jarak pagar. Dari hasil uji ANOVA diperoleh $p$ value sebesar 0,00 $(p<0,05)$ yang berarti ada pengaruh pemberian ekstrak biji jarak pagar terhadap berat testis. Untuk melihat signifikasi antar kelompok perlakuan dilanjutkan dengan uji Post Hoc Test Multiple Comparisons jenis Bonferroni.

Berdasarkan hasil uji Post Hoc Test Multiple Comparisons jenis Bonferroni pada tabel 4 terlihat bahwa kelompok perlakuan yang berpengaruh secara signifikan dalam menurunkan berat testis adalah kelompok kontrol P1 dengan P2 dan P1 kelompok P3, 
sedangkan kelompok P2 tidak berhubungan dengan P3 $(p>0,05)$.

Terjadinya penurunan berat testis disebabkan oleh terhambatnya perkembangan sel leydig yang disebabkan oleh sekresi LH yang menurun akibat efek Jatrophone, flavonoid dan alkaloid yang terkandung pada ekstrak biji jarak pagar. Dugaan lain penurunan berat testis juga disebabkan oleh menurunnya FSH yang memiliki fungsi penting dalam proses spermatogenesis.

Hasil penelitian tersebut sejalan dengan penelitian Raji dkk pada tahun 2006 yang menunjukkan bahwa terdapat penurunan yang signifikan $(p<0,01)$ pada berat organ-organ reproduksi, fungsi sperma dan level testosteron serum tikus pada kelompok perlakuan yang diberikan ekstrak biji jarak kepyar. ${ }^{18}$ Penelitian Puspitadewi dan Sunarno pada tahun 2007 mendapatkan bahwa terdapat perubahan berat uterus pada tikus betina kelompok perlakuan dibandingkan dengan kelompok kontrol pada pemberian larutan serbuk biji jarak pagar. ${ }^{19}$ Penelitian Tolera tahun 2004 menunjukkan bahwa terdapat penurunan berat uterus dan ovarium pada mencit Swiss albino pada pemberian ekstrak biji jarak pagar. $^{20}$

Peran fundamental FSH bersama dengan testosteron adalah mempertahankan spermatogenesis. Saat ini diyakini bahwa FSH menstimulasi sel sertoli untuk memproduksi cAMP yang menstimulasi sintesis protein spesifik yaitu protein pengikat androgen (Androgen-Binding Protein, $A B P$ ), yang disekresikan ke dalam lumen tubulus seminiferus. Sel sertoli juga memproduksi nutrisi yang dibutuhkan untuk pertumbuhan dan diferensiasi spermatozoa. LH menstimulasi sel leydig untuk memproduksi testosteron, yang berikatan dengan $\mathrm{ABP}$, dan kompleks tersebut membawa testosteron mendekat ke spermatosit yang sedang berkembang. ABP mungkin juga berfungsi meningkatkan konsentrasi lokal testosteron dan mentranspor hormon ini ke epididimis. Sel leydig juga mensintesis estrogen yang berikatan dengan $\mathrm{ABP}$, dan bersifat esensial bagi spermatogenesis yang normal. $^{21}$ Apabila testosteron di dalam sel leydig berkurang, maka akan mengakibatkan pembelahan meiosis terganggu, sehingga pembentukan spermatid dan seterusnya juga akan terganggu. Menurut penelitian Fritz tahun 2003, penyusutan berat testis telah dilaporkan berhubungan dengan penyusutan dimensi tubulus seminiferus sebagai tempat utama berlangsungnya proses spermatogenesis untuk menghasilkan spermatozoa. Berdasarkan penelitian Sherwood pada tahun 2001, tubulus seminiferus merupakan bagian utama massa testis, yaitu sekitar $80 \%{ }^{22}$

Berdasarkan hasil penelitian terlihat bahwa terjadi penurunan diameter testis mencit jantan setelah dilakukan pemberian ekstrak jarak pagar dengan beberapa tingkat dosis. Terdapat perbedaan yang bermakna diameter testis antar kelompok perlakuan P1, P2, dan P3 setelah diberikan ekstrak biji jarak pagar.

Pada Tabel 5 menunjukkan adanya penurunan rata-rata diameter testis pada kelompok yang diberi ekstrak biji jarak pagar pada mencit jantan. Dari hasil uji ANOVA diperoleh $p$ value sebesar $0,00(p<0,05)$ yang berarti ada pengaruh pemberian ekstrak biji jarak pagar terhadap diameter testis. Untuk melihat signifikasi antar kelompok perlakuan dilanjutkan dengan uji Post Hoc Test Multiple Comparisons jenis Bonferroni.

Berdasarkan hasil uji Post Hoc Test Multiple Comparisons jenis Bonferroni pada tabel 6 dapat disimpulkan bahwa semua kelompok perlakuan berhubungan secara signifikan dalam menurunkan diameter testis. Kelompok P1 berhubungan dengan P2 dan P3 dan kelompok P2 juga berhubungan dengan kelompok P3 $(p<0,05)$.

Terjadinya penurunan diameter testis diduga disebabkan oleh berkurangnya sekresi testosteron karena terhambatnya perkembangan sel leydig yang disebabkan oleh sekresi LH yang menurun akibat efek Jatrophone, flavonoid dan alkaloid yang terkandung pada ekstrak biji jarak pagar. Dugaan lain penurunan diameter testis juga disebabkan oleh menurunnya FSH yang memiliki fungsi penting dalam proses spermatogenesis. Kurangnya hormon testosteron dan FSH inilah yang diduga menyebabkan atropi pada tubulus-tubulus seminiferus, akibatnya diameter testis menjadi berkurang.

Hasil penelitian tersebut sejalan dengan penelitian Raji dkk pada tahun 2006 yang menunjukkan bahwa pada pemberian ekstrak biji jarak 
kepyar pada kelompok perlakuan terdapat disorganisasi cytoarchitecture testis, disrupsi tubulus seminiferus, dan erosi epitelium germinal. ${ }^{18}$ Penelitian yang dilakukan oleh Puspitadewi dan Sunarno pada tahun 2007 yakni melihat pengaruh larutan serbuk biji jarak pagar terhadap profil uterus mencit betina didapatkan bahwa terdapat perubahan tebal endometrium uterus pada tikus betina kelompok perlakuan dibandingkan dengan kelompok kontrol. ${ }^{19}$

\section{KESIMPULAN}

Dari hasil penelitian ini disimpulkan bahwa pemberian ekstrak biji jarak pagar dapat menurunkan jumlah spermatozoa, spermatozoa motil, berat testis dan diameter testis namun secara statistik ekstrak biji jarak pagar tidak terdapat pengaruh yang bermakna terhadap jumlah spermatozoa dan spermatozoa motil dan terdapat pengaruh yang bermakna terhadap berat testis dan diameter testis.

\section{DAFTAR PUSTAKA}

1. SDKI. Survey Demografi dan Kesehatan Indonesia. Jakarta: Kementerian Kesehatan, BKKBN dan BPS; 2012.

2. BKKBN. Peningkatan Partisipasi Pria Dalam Keluarga Berencana dan Kesehatan Reproduksi. Jakarta; 2003.

3. Erlysa $W$ dan Trisnawarman D. Sistem Penunjang Pemilihan Metoda/alat Kontrasepsi. Gematika; 2007.

4. Elya B dan Kusmana D. Pengaruh infus daun Puding (Polyscias guilfoylei L.H. Bailey) terhadap kualitas spermatozoa tikus jantan (Rattus norvegicus) Galur DDY. Makara Sains. 2002; 6(2):99-104.

5. Cambie R dan Brewis A. Anti Fertility Plants of the Pacific. CSIRO. Australia; 1999.

6. Ekwere O, Rosaleen TM, Francis K. The Effect of Ricinus communis-Linn (RICOM 1013-J) on Semen Parameters: a comparative study. JPCS 2011; Vol 1: 7-11.

7. Nurcholis M dan Sumarsih S. Jarak Pagar dan Pembuatan Biodiesel. Yogyakarta. Kanisius; 2007.
8. Departemen Kesehatan Republik Indonesia. Inventaris Tanaman Obat Indonesia (I) Jilid 2. Jakarta; 2000

9. Nurmillah O. Kajian Aktivitas Antioksidan dan Antimikroba Ekstrak Biji, Kulit Buah, Batang dan Daun Tanaman Jarak Pagar (Jatropha curcas I.). ejournal upnjati. Bogor: Fakultas Teknologi Pertanian Institut Pertanian Bogor; 2009.

10. Nath S, Dutta C, Roychoudhury S, Talukdar A, Misro M. Male Contraceptive Efficacy of Ricinus communis L. Extract. Journal Ethnopharmacol. 2013; Vol.149(1): 328-34.

11. Wurlina, Sastrowardoyo W, dan Meles D. Pengaruh Antimitosis Ekstrak Achyranthes aspera linn pada pembelahan Sel Embrio (Cleavage) dalam Upaya penemuan Obat Antifertilitas setelah Hubungan Seksual (Post Coital Contraception). Lemlit. Unair; 2003.

12. Nithya R, Anuja M, Swathy S, Rajamanickam C, Indira M. Effects on Spermatogenesis in Swiss Mice of a Protein Isolated from the Roots of Ricinus communis (Linn) (Euphorbiaceae). India: Department of Biochemistry. University of Kerala. 2011; 187(1-3): 386-92.

13. Sudarmaji dan Herawati N. Ekologi Tikus Sawah dan Teknologi Pengendaliannya. Padi: Inovasi Teknologi Produksi. Buku 2. Jakarta. LIPI Press; 2009.

14. Sandhyakamuri K, Bobby R, Indira M. Antifertility Effects of Ricinus communis (Linn) on Rats. Phytoterapy Research. Jhon Willy \& Sons. 2003; 17.5. 508-11.

15. Ashfahani $E$, Wiratmini $N$, Sukmaningsih $A$. Motilitas dan Viabilitas Spermatozoa Mencit (Mus musculus I.) Setelah Pemberian Ekstrak Temu Putih (Curcuma zedoaria (berg.) Roscoe.). Jurnal Biologi. Fakultas Biologi Universitas Udayana. $2010 ; 14(1): 20-3$.

16. Ganong, Barret K, Barman S, Boitano S. Brooks H. Ganong's Review of Medical Phisiology Twenty Third Edition. United States: The Mac Graw Hill Companies; 2011.

17. Hayati A. Kajian Kualitas dan Protein Membran Spermatozoa Tikus (Rattus norvegicus) Akibat Pemaparan 2-Methoxyethanol, Disertasi, Universitas Gadjah Mada, Yogyakarta; 2007. 
18. Raji Y, Oloyo A, Morakinyo A. Complementary Medicine: Effect of Methanol Extract of Ricinus Communis Seed on Reproduction of Male Rats. Asian Journal of Andrology. 2006; Vol.8(1). 11521.

19. Puspitadewi S dan Sunarno. Potensi Agensia Antifertilitas Biji Tanaman Jarak (Jatropha curcas) dalam Mempengaruhi Profil Uterus Mencit (Mus Musculus) Swiss Webster. Jurnal Sains dan Matematika. 2007; Vol.15(2). 55-60.

20. Tolera A. The Effect of Ricinus communis and Jatropha curcas Seed Aqueos Extracts on The Histology of Uterus and Ovary in Mice. A Thesis Submitted to The School of Graduate Studies Of Addis Ababa University in Partial Fulfillment Of the Requirements of Masters of Science Degree in Anatomy; 2004.

21. Greenstein B dan Wood D. At A Glance Sistem Endokrin (Edisi Kedua). Jakarta: Erlangga; 2010.

22. Fritz W, Wan J, Eltoum I, Lamartienere C. Dietary Genistein Down-Regulates Androgen and Estrogen Receptor Expression in the Rat Prostate. Mole Cell Endocrinol. 2002; 186: 89-99. 